\title{
FRUIT PRODUCTION IN THE SETTLEMENTS OF THE EGER WINE REGION FROM THE MIDDLE OF THE 19TH CENTURY TO THE BEGINNING OF THE 20TH CENTURY
}

\author{
Sándor Rózsa
}

\begin{abstract}
Carrying out a historical statistical analysis of fruit production is a relatively difficult task, as the sector played a complementary role in traditional peasant farming; it appeared only rarely in trade and tax-related resources, and it was not only after its increase in market share that state agricultural statistics paid attention to it. The national agricultural censuses of 1895 and 1935 recorded the fruit tree population of the individual settlements in a distribution by species. Their data, supplemented by other sources (county monographs, contemporary press materials, etc.), are suitable for assessing the significance of the sector and for analyzing changes at the turn of the century. In the settlements of the Eger wine region, traditional varieties of fruit production, characterized by combined cultivation (e.g. fruit trees planted between vine rows) and a high proportion of less demanding species, began to fade into the background only slowly; there was, however, a shift towards market-oriented more intensive production.
\end{abstract}

Keywords: agricultural history, Eger wine region, fruit production, agricultural census, CODE: B19 agricultural statistics 


\section{Introduction}

In this paper, I present the fruit production of the settlements of the Eger wine region from the mid-19th to the early 20 th century, focusing primarily on the importance of the sector, its market orientation, production system, variety composition and changes in the area of these. Fruit production in the area has received little attention in agricultural research so far, and ethnographic (ethnopomological) research, which undoubtedly revealed a great deal of information on the fruit culture of earlier centuries, has usually dispensed with deeper statistical analyzes. Grape and fruit production were closely related to each other in traditional peasant farming, and in this respect it is entirely relevant to examine the settlement group.

Carrying out a quantitative analysis of fruit production in the period prior to the publication of state agricultural statistics censuses is difficult, since peasant fruit production, mainly for self-sufficiency, is hardly mentioned in administrative documents related to taxation and trade. The complementary nature of fruit production was also reflected in the fact that it was not an independent area: fruit trees were usually planted between the vine rows, in gardens belonging to the house or on pastures and meadows, and there was little fruit production in monocultures until the early 20th century. However, many sources testify to the long tradition of selling fruit on the market, and its value was greatly appreciated in some periods of crisis.

\section{Sources}

During the investigation, I evaluated the fruit production of the settlement group according to the agricultural census of 1895 and 1935, supplemented by the work of Ferenc Albert of Montedego and Samu Borovszky presenting Heves county, as well as an article on fruit production published in the local press (the daily paper called Eger).

The Department of Statistics, set up in 1868 within the framework of the Ministry of Agriculture, Industry and Commerce, and the independent National Royal Hungarian Statistical Office, established from the former in 1871, paid special attention to exploring the state of agriculture, and due to this the first censuses on certain sub-areas of agriculture were carried out: (1968: first harvest statistics, 1873: viticulture statistics), and later the first comprehensive agricultural census in the history of Hungary. (Laczka, 2000) The agricultural census ordered by statute VIII was intended to be extended to all areas of farming, ranging from property relations through livestock and agricultural equipment to fruit production.

It was important to reconcile the modern statistical approach with local farming practices, which in many cases had unique, archaic elements. As for fruit production, 
if only plants grown in modern monocultures had been taken into account, the supplementary sector would have remained almost invisible. To eliminate this problem, fruit trees were recorded by number, regardless of their location. The significance of this becomes clear when we compare the editions of the 1935 census. The main data on the plants of the Hungarian agriculture in the publication entitled in the Year 1935 give only the fruit tree population of the "separated orchards", so the majority of the tens of thousands of fruit tree population of the settlements was left out of the summary work.

During the two large censuses, the number of fruit trees was summarized by species. In 1895, the number of apples, pears, cherries, peaches, apricots, plums, nuts, almonds, chestnuts and mulberries was given, and in 1935 it was supplemented with quince, pineapple and peanuts. In 1935 it was also a novelty to record the number of plums in the categories of free stone, "other kind" and greengage. To facilitate statistical evaluation, I treated prunes and pomaceous ones (apple and quince) together.

\section{Results}

\section{About the 19th century fruit production in Heves County in general}

In his work of 1868, Ferenc Albert described the fruit production of the county as the average, which played a complementary role in addition to grape production. It had a greater priority only in the lowland areas less suitable for grape production where vineyards were in fact more like orchards. Of the mountain settlements, he picks out Eger, where summer fruit production was very significant, especially that of peaches, which were also delivered in larger quantities to the markets of the settlements along the river Tisza. However, the production of winter fruits was not enough to satisfy the local market needs, either and the market of Eger was supplied with fruits from other regions. According to Albert, the main reason for this was that farmers did not have sufficient storage capacity. (Albert, 1868)

Samu Borovszky wrote about a dynamically growing fruit production sector at the beginning of the 20th century, within which the production of cherries, walnuts and sour cherries, and that of the autumn and summer's peaches were especially significant. Due to the development of the transport infrastructure, the volume of fruit sold continued to increase; only in 1909 there were 420 wagons of cherries transported by rail from Gyöngyös and Eger. He pointed out, however, that fruit production continued to be considered as a secondary activity, with most of the trees scattered among the vines; a significant number of them was not even pruned. (Borovszky, 1909)

The Heves County Economic Association, established in 1858, aimed from the beginning to revive the fruit production of the county. It was considered a priority to domesticate and distribute fruit varieties that are well adapted to the local conditions 
of the production site and can be sold well on the market. (Eger, 1868.05.11) To this end, a pilot garden was established in Gyöngyös, where fruit trees were also propagated. By 1864, 87 apple and 80 pear seedlings were available in the pilot garden. (Eger, 13.10.1864) By the end of the decade, however, the members of the association complained about the obsolescence of the gardens and deficiency of maintenance. (Eger, 06.09.1877)

The county economic association, together with other local associations (e.g. the Tiszafüred Fruit Association), besides the operation of the nursery gardens, sought to encourage professional fruit production by organizing various exhibitions and establishing awards. (Eger, 13.10.1864) The National Hungarian Economic Association organized a fruit exhibition in Pest every year and the county association announced their invitation from time to time. (Eger, 28.07.1881) However, we have no information about how many owners of the winegrowing area and with what results took part in them. In 1864, a ministerial prize was announced for fruit and vegetable growers, and an association with an area of operation extended to Jászság at that time proposed a producer in Jászberény and one in Jászárszállás. (Eger, 14.09.1871) In 1881 according to the weekly paper called Eger Béla Kempelen won bronze medals for his potatoes exhibited at the national exhibition; the fruit was, however, not shown by the people of Eger. (Eger, 27.10.1881) From the 1880s, the newly established Tiszafüred Fruit Society organized a fruit and vegetable horticultural exhibition every year, with a gradual increase in the number of participants, but we do not know how many growers from around Eger participated in them. (Eger, 10.02.1884)

Towards the turn of the century, several articles were published that sought to encourage professional fruit production. These articles sadly noted that, despite optimum production conditions and improved sales opportunities, little attention was paid to fruit production in Eger. The poor quality of the fruit produced was identified as the biggest obstacle to exploiting market opportunities. (Eger, 16.12.1886) In the market of Eger a decree was issued concerning the quality of the fruit sold, prohibiting the sale of unripe fruit. After the destruction caused by phylloxera, fruit production became more important, and many saw it as an opportunity to alleviate the problems of making ends meet and emphasized the risk-reducing effect of combined cultivation.

By the end of the century, formerly state-sponsored silkworm rearing and, in connection with this, mulberry planting, were in sharp decline. Economic articles already emphasized the importance of mulberry distillery and foraging, but the population was reduced. (Eger, 22.2.1880)

\section{Fruit production in the settlements of the Eger wine region at the end of the 19th century}

According to the data of the 1895 census, stone fruits were produced in the largest proportion in the settlements of the Eger wine region. At the beginning of the study, 
I assumed that the less demanding fruit species that produce fruits to be preserved better would form a larger part of the population. This was confirmed by data of the survey, as plum trees accounted for $50 \%$ of the total population within the stone fruits. The data of the census did not confirm Ferenc Albert's statement regarding peach production, since the proportion of peach trees in Eger did not exceed 5\%. Albert's statement was therefore limited to the greater proportion of peaches in the total marketed fruit.

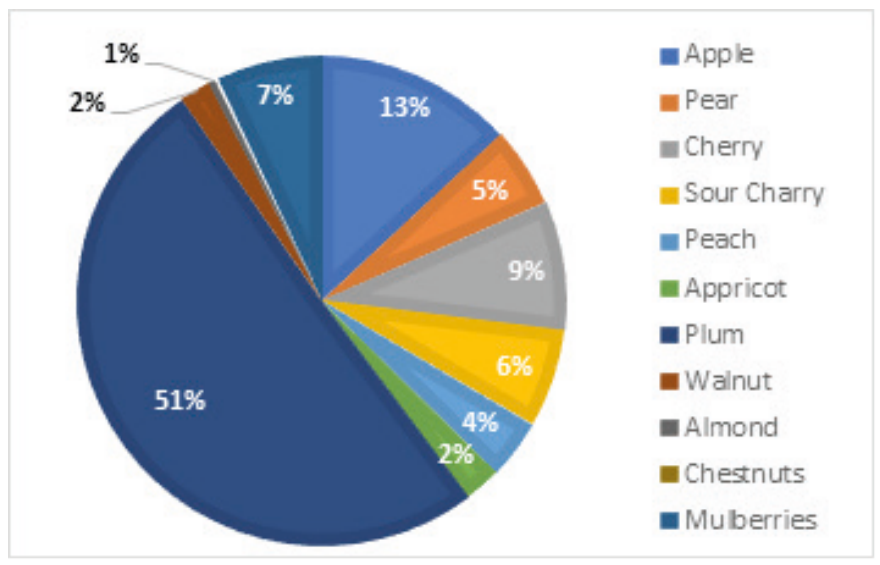

Figure 1: Distribution of fruit tree stock by species in the Eger wine region in $\mathbf{1 8 9 5}$ Source: Agricultural Census of 1895 by the Hungarian Royal Central Statistical Office.

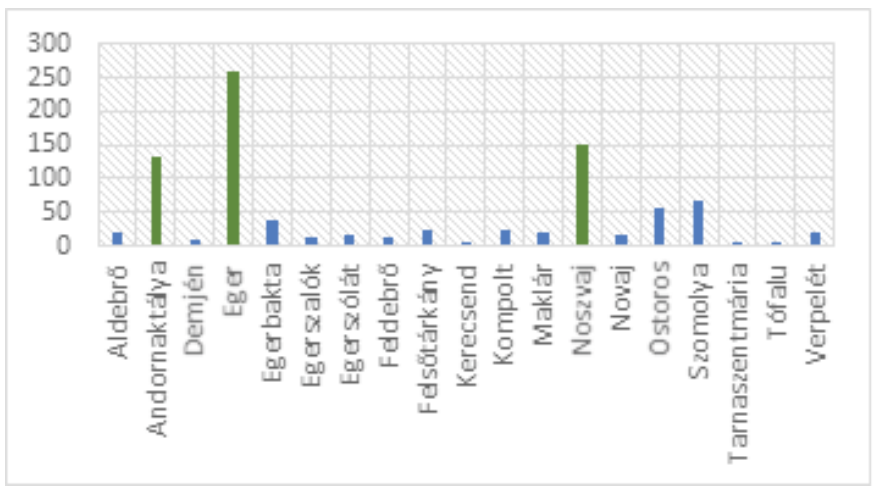

Figure 2: The number of fruit trees per farm in the settlements of the Eger wine region Source: Agricultural Census of 1895 by the Hungarian Royal Central Statistical Office.

In terms of quantity, the fruit tree population of the settlement group was not outstanding either at county level or state level, and the racial composition did not show any significant difference, either. At county scale, the apple population 
(30.81\% of the county's population) and the mulberry population $(31 \%$ of the county's population) were outstanding, while the higher proportion of sour cherries and plums within the stone fruits slightly differed from the county average.

In terms of the number of fruit trees per farmer, five settlements stood out: Eger, Noszvaj, Andornaktálya, Ostoros and Egerbakta. Eger accounted for nearly thirty percent of the total tree population of the settlement group, which is probably due to the better sales opportunities offered by the local market and the greater proportion of wine growing areas. Compared to other settlements in the wine region, the proportion of the apple and sour cherry trees was relatively high. The populations of Noszvaj, Ostoros and Szomolya belong to one group in terms of racial composition, and in their case cherry production is significant compared to other settlements. The population of the Andornaktálya mostly differs from the average in the wine region in terms of the more even proportion of species, while the Egerbakta stood out with the high proportion of the plum tree population.

\section{Fruit production in the settlements of the Eger wine region in the first half of the 20th century}

The 1935 census shows only a 5\% increase in population compared to the 1895 census, but the composition of the population by species changed significantly. The proportion of plums that used to account for $51 \%$ of the population fell to $32 \%$, while that of the peaches increased by nearly $10 \%$ and that of apricots by $7 \%$. The proportion of pome fruits and shelled fruits increased slightly compared to that of stone fruits. An increase in the proportion of more demanding and valuable species indicates an increase in market orientation.

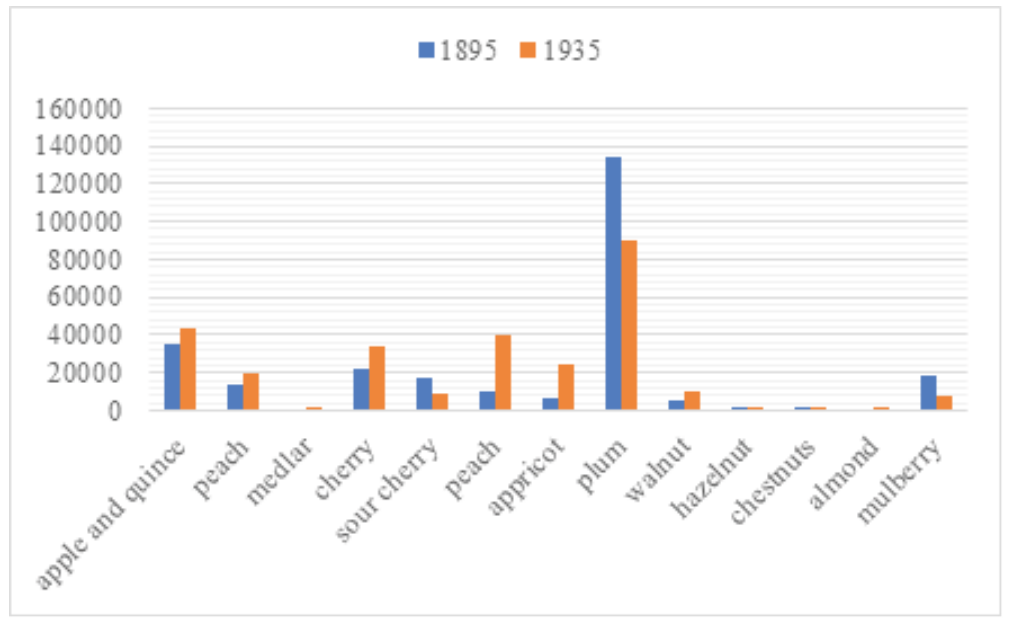

Figure 3: The number of fruit trees per species in the Eger wine region in 1895 and 1935 Source: Agricultural Census of 1895 by the Hungarian Royal Central Statistical Office. 
In 1935, Maklár, Verpelét and Aldebrő were among the settlements with the most significant fruit tree population while Egerbakta was one of the settlements with the smallest population. It can be observed that it increased in the southern settlements of the wine region, while in the north - in the more mountainous areas - the number of fruit trees decreased. This is probably due to the fact that the areas with more favorable conditions for fruit production could lend themselves to more intensive fruit production to a greater degree, and thus the decrease in the population resulting from the decline in the use of the traditional methods of fruit production could be more compensated by the advance of market oriented fruit production. For example, the plum tree population of Egerbakta fell significantly compared to 1895, while catching-up Verpelét, where it grew by more than 300\%, was already dominated by more marketable species, apples, pears, cherries and peaches.

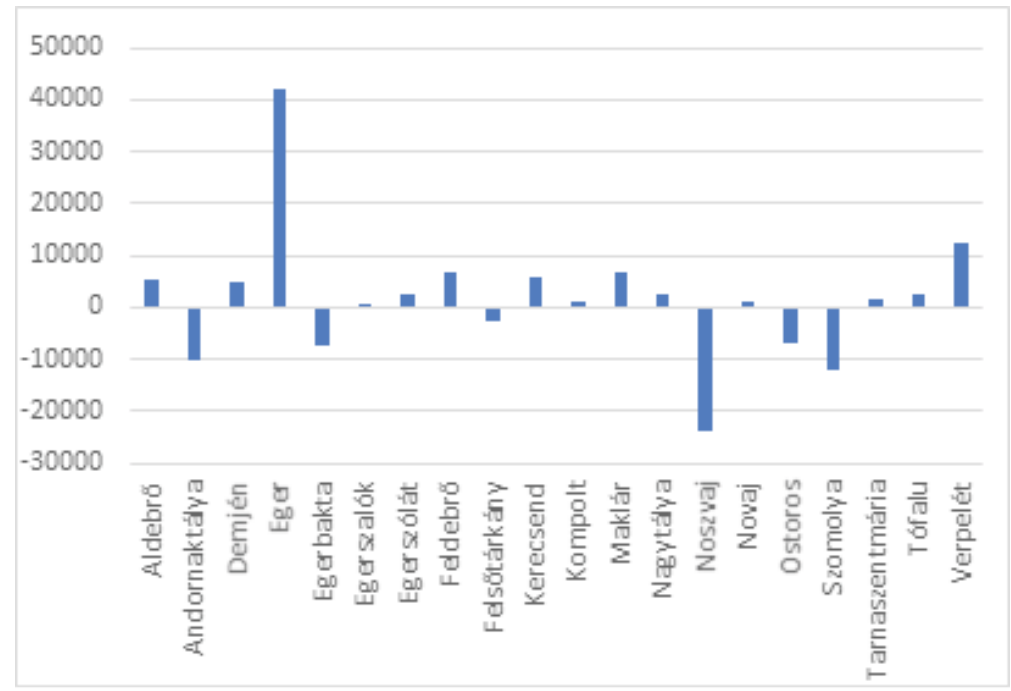

Figure 4: Change in population compared to 1895

Source: Agricultural Census of 1895 by the Hungarian Royal Central Statistical Office.

It is an interesting point, however, that Andornaktálya, Ostoros and Szomolya experienced a significant decline in fruit tree population, although they were settlements traditionally having a more significant fruit production and a higher proportion of production for market. I cannot explain why it decreased in their case; however, it was striking that the increase in the number of farms was the smallest in these cases, i.e. it can be related to the structure of the landed properties of the settlements. Considering that a large proportion of fruit trees were still planted in small gardens and the number of fruit trees planted between vine rows was increasingly scarce on the vine parcels of large estates, the number of farms and the size of fruit tree population could have been closely related. 
An important issue is how big the proportion of professionally and intensively cultivated trees planted primarily for market sale was within the total fruit tree population. Trees planted in the backyards of houses, among the vines or in the vegetable gardens, could have formed only a minor part of this category; however, the trees of an area planted with fruit trees in monocultures fall into this category in great number. The census of 1895 and 1935 does not apply an independent orchard category in the cultivation branches, the data of the cadastral survey was taken over, where purely orchards fell into the main category of gardens, including vegetable gardens and ornamental gardens, thus their expanse cannot be determined.

The data of the 1935 census were also published by the Statistical Office in several publications: Property relationships of Hungary in 1935, Livestock, farm equipment and fruit tree population of Hungary in 1935, The main plant data of Hungarian agriculture in 1935, etc., the latter only gives only the tree population of the 'separated orchards' of the settlements. Comparing these data with the data of other publications, which gave the whole population, it can be stated that in 1935 orchards cultivated in monocultures were to be found only in Aldebrő, Andornaktálya, Eger, Egerszólát, Noszvaj and Tófalu. Their fruit tree population accounted for $1.5 \%$ of the total population of the wine region. The species ratios of the separated orchards did not significantly differ from the proportion of the total population.

\section{Conclusions}

The main objective of agricultural history research is to study the process by which traditional agriculture has become modern market-oriented farm agriculture. An important contribution to this assessment is mapping the changes in the fruit production sector. Fruit production was closely related to wine production; nevertheless, the fruit production of the examined wine region was not more significant than that of other areas of the county. At the end of the 19th century, two processes had an effect time within fruit production at the same. The development of transport infrastructure significantly improved the possibilities of selling fruit, which is well reflected in the transformation of the species structure, i.e. the increase in the proportion of more valuable fruit species. However, a large part of the peasant farm's tree population was fruit trees planted between vine rows, gardens, meadows or just off the roads, and this cultivation system did not match the production of more demanding and marketable fruit species. In this way, we can simultaneously witness a decline in peasant fruit production (in parallel with a decline in the self-sufficiency of the peasant farms) and an increase in the population cultivated more intensively. The small increase in tree population between 1895 and 1935 is presumably due 
to the two opposite processes. Farmers of the time called attention to the fact that fruit production could be an alternative to vine production during the time of the phylloxera plague, but it cannot be determined to which extent it was realized. The effect of the phylloxera plague on fruit production may be an interesting area for future research. It is difficult to provide a comprehensive analysis of the fruit production of a settlement or region due to the limited number of sources available. Although the statistical sources used in the study provide an opportunity for a relatively thorough analysis, possible distortions of data are to be expected, it is especially true in the case of the 1935 census. Changes in the fruit tree population of the settlements (e.g. the decrease in the population of Ostoros, Szomolya and Andornaktálya) are difficult to explain in some cases, so further investigation is needed. Thus, the study completed may be the preparation of a larger study that identifies the places where to go deep into the archives.

\section{Reference sources}

[1.] Albert Ferenc (1868): Heves és Külső Szolnok törvényesen egyesült vármegyék leírása. [Description of the the legally united Heves County and Outer Szolnok County].

[2.] Borovszky Samu (szerk.) (1909): Magyarország vármegyéi és városai. Heves vármegye. [Counties and cities in Hungary. Heves County]. Budapest.

[3.] Laczka Sándorné (2000): Mezőgazdasági összeírások Magyarországon, 18952000. [Agricultural Censuses in Hungary, 1895-2000]. Statisztikai Szemle, 78. évf., 4. sz. 282-289.

[4.] Konkoly-Thege Gyula (szerk.) (1941): Magyarország mezőgazdaságának fóbb üzemi adatai az 1935. évben a gazdaságok (üzemek) nagysága szerint. [The main plant data of Hungarian agriculture in 1935 according to the size of the farms (plants)]. Magyar Statisztikai Közlemények 112. Budapest, Magyar Királyi Központi Statisztikai Hivatal, 721. o.

[5.] Szöllősy Zoltán (szerk.) (1937): Magyarország állatállománya, gazdasági gépfelszerelése és gyümölcsfaállománya az 1935. évben törvényhatóságok és községek szerint. [Livestock, farm equipment and fruit tree population of Hungary in 1935 according to municipalities and villages]. Magyar Statisztikai Közlemények 100. Budapest, Magyar Királyi Központi Statisztikai Hivatal, 397. o. 
[6.] Sajóhelyi István (szerk.) (1937): Magyarország földbirtokviszonyai az 1935. évben I. Törvényhatóságok és községek (városok) szerint. [Property relationships of Hungary in $1935 \mathrm{I}$. According to municipalities and villages]. Magyar Statisztikai Közlemények 99. Budapest, Magyar Királyi Központi Statisztikai Hivatal, 1050. o.

[7.] Keleti Károly (szerk.) (1897): A Magyar Korona országainak mezőgazdasági statisztikája. 1. rész. A magyar mezőgazdasági statisztika fejlődése $s$ az 1895. évi VIII. törvényczikk alapján végrehajtott összeírás föbb eredményei községenként. [Agricultural statistics of the countries of the Hungarian Crown. Part 1. The development of Hungarian agricultural statistics and the main results of the census carried out in accordance with the statute VIII from village to village]. Magyar Statisztikai Közlemények Új Folyam. 15., Budapest, 765. o.

[8.] Eger hetilap (1865.05.11): Hevesmegye gazdasági egyesülete igazgatósági választmánya 1865-ik év máj. 1-én Gyöngyösön tartott rendes havi ülés jegyzőkönyve. [The minutes of the regular monthly meeting of the Board of Directors of Heves County Economic Association held in Gyöngyös on May 1, 1865.]. III. évf.,19. sz., 1. o

[9.] Eger hetilap (1877.09.06): Heves Vármegye és a Jászkerület gazdasági egylete folyó évi augusztus 21-én tartott rendes közgyüléséről. [About the Annual General Meeting of the Economic Association of Heves County and Jász District held on August 21st this year]. XVI. évf., 36. sz. 285. o.

[10.] Eger hetilap (1864.10.13): Melléklet az „Eger” 41. számához. [Appendix to „Eger” issue 41]. II. évf., 41. sz.

[11.] Eger hetilap (1864.10.13): Az egri gyümölcstermelökhöz. [For the fruit growers in Eger]. II. évf., 41. sz., 326. o.

[12.] Eger hetilap (1884.10.02): Tiszafüredi gyümölcs- és konyhakertészeti kiállítás. [Fruit and vegetable gardening exhibition in Tiszafüred]. XXIII. évf., 40. sz., 370. o.

[13.] Eger hetilap (1881.07.28): Gyümölcs- és kertészeti kiállítás Budapesten. [Fruit and horticulture exhibition in Budapest]. XX. évf., 30. sz., 327. o.

[14.] Eger hetilap (1881.10.27): Beszámoló a hírfüzérben a gyümölcs- és kertészeti kiállításokon elért eredményekről. [Report on the results achieved at the fruit and horticultural exhibitions in the news.]. XX. évf., 43. sz., 466. o.

[15.] Eger hetilap (1881.09.14): Heves vármegye és a Jászkerület gazdasági egyesülete részéről Gyöngyösön 1871-ik év augusztus hó 20-án tartott rendes 
évi közgyülésének jegyzőkönyve. [Minutes of the regular annual general meeting of the Economic Association of Heves County and Jász District held on August 20, 1871]. IX. évf., 37. sz., 292. o

[16.] Eger hetilap (1886.11.16): Ültessünk gyümölcs-fákat! [Let's plant fruit trees!]. 25. évf., 46. sz., 366-367. o.

[17.] Eger hetilap (1880.02.12): Néhány szó az eperfa- és selyemtenyésztés érdekében. [A few words for mulberry production and silk worm rearing.]. XIX. évf., 7. sz., 51-52. o. 